\title{
A biodegradable porous composite scaffold of PCL/BCP containing Ang-(1-7) for bone tissue engineering
}

\section{(Um suporte compósito poroso biodegradável de PCL/BCP contendo Ang-(1-7) para engenharia de tecido ósseo)}

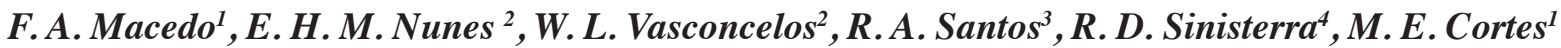 \\ ${ }^{I}$ Dentistry Faculty, ${ }^{2}$ Department of Metallurgical and Materials Engineering - Engineering School, \\ ${ }^{3}$ Department of Physiology and Biophysics, ${ }^{4}$ Chemistry Department \\ Federal University of Minas Gerais - UFMG, Av. Antonio Carlos 6627, Belo Horizonte 31270-901, MG, Brazil \\ mecortes@yahoo.com
}

\begin{abstract}
Highly porous three-dimensional biodegradable scaffolds was obtained from beta-tricalcium phosphate-hydroxyapatite bioceramic (BCP), PCL, and Angiotensin-(1-7). We used the solvent casting and particulate leaching methods (SC/PL). The processed scaffolds were characterized by X-ray microtomography $(\mu-\mathrm{CT})$. Biocompatibility tests in vitro were performed during three and seven days using MTT and Alkaline Phosphatase Activity (APA) assays. Both the MTT activity and APA were evaluated using a one-way ANOVA test. The $\mu$-CT results showed that the increase of the PCL:BCP weight ratio leads to structures with lower pore sizes. The pore interconnectivity of the processed scaffolds was evaluated in terms of the fragmentation index (FI). We observed that the obtained composites present poorly connected structures, with close values of FI. However, as the polymer phase is almost transparent to the $\mathrm{X}$-rays, it was not taken into consideration in the $\mu$-CT tests. The MTT activity assay revealed that scaffolds obtained with and without Angiotensin-(1-7) present mild and moderate cytotoxic effects, respectively. The APA assay showed that the rat osteoblasts, when in contact for three days with the PCL composites, presented an APA similar to that observed for the control cells. Nevertheless, for an incubation time of seven days we observed a remarkable decrease in the alkaline phosphatase activity. In conclusion, using the solvent casting and salt leaching method we obtained 3D porous that are composites of PCL, BC and Ang-(1-7), which have suitable shapes for the bone defects, a high porosity and interconnect pores. Furthermore, the viability in vitro showed that the scaffolds have potential for drug delivery system and could be used in future in vivo tests.
\end{abstract}

Keywords: angiotensin-(1-7), composite, scaffold, tissue engineering.

\section{Resumo}

A estrutura de um biomaterial para regeneração óssea é fator chave para seu sucesso clínico. Não existe um único biomaterial usado para reparo e regeneração óssea capaz de preencher todos os requisitos para um enxerto ósseo ideal. Assim, optou-se por utilizar neste estudo dois biomateriais largamente utilizados na engenharia de tecido ósseo, a policaprolactona (PCL) e cerâmica bifásica $(B C P)$. Neste estudo, compósitos porosos tridimensionais de PCL:BCP (3:1 e 1:1 p:p) foram fabricados utilizando a combinação das técnicas de evaporação do solvente e lavagem de partículas de sal com ou sem a adição de Angiotensina (Ang)-(1-7). Os compósitos de PCL:BCP com alta porosidade e interconectividade obtidos foram analisados usando microtomografia computadorizada ( $\mu$-CT). A viabilidade dos compósitos com e sem a adição da Ang-(1-7) foram analisados utilizando osteoblastos de cultura primária nos períodos de 3 e 7 dias utilizando o teste de MTT e secreção de Fosfatase Alcalina. Diferenças significativas de todas as variáveis foram testadas através de análises multivariáveis $(p<0,05)$. Demonstrou-se uma estrutura mais uniformemente distribuída quando a razão PCL/BCP foi aumentada. A conectividade dos poros foi mensurada através do índice de fragmentação (FI) demonstrando estruturas desconexas nas amostras analisadas possuindo valores de FI próximos. Quanto maior a razão PCL/BCP, maior a dimensão fractal (FD). Análises in vitro utilizando o teste do MTT demonstraram que as amostras contendo ou não Ang-(1-7) possuíram efeitos citotóxico médio e moderado, respectivamente. A análise da atividade de fosfatase alcalina não monstrou diferença entre as amostras no período de 3 dias decrescendo sua atividade nas amostras contendo Ang-(1-7) no período de 7 dias. Dessa forma, utilizando a combinação das técnicas de evaporação do solvente e lavagem do sal, obtiveram-se estruturas porosas tridimensionais, desejável para defeitos ósseos tendo capacidade para sistema de transporte de drogas podendo ser avaliada em futuros testes in vivo.

Palavras-chave: compósitos, angiotensina-(1-7), micro tomografia, cerâmicas bifásicas, policaprolactona, viabilidade in vitro.

\section{INTRODUCTION}

Current treatment strategies for degenerative diseases and damaged bone tissue include autografts, allografts, xenografts, and artificial materials such as metals and bioceramics [1]. Novel strategies are necessary because of the limitations related to these treatments such as inadequate tissue supply, potential for disease transfer, and compliance issue [2].

Bone tissue engineering involves methods from materials 
engineering and life sciences to create artificial constructs for regeneration of new bone [3]. A key component in tissue engineering for bone regeneration is the scaffold that acts as a template for cell interactions and the formation of boneextracellular matrix that provides mechanical support to the newly formed tissue. Scaffolds for bone regeneration must meet several criteria in order to serve this application, including adequate mechanical stability to provide a suitable environment for the formation of new bone tissue, and biodegradability at a rate commensurate with remodeling. In addition, scaffolds also can act as drug delivery vehicles and promote bone tissue ingrowth through them [4].

Currently, composites of polymers and ceramics have been developed with the purpose to increase the scaffold mechanical stability and improve tissue interactions. Calcium phosphate ceramics have been widely used as synthetic bone graft substitutes for over 30 years in dental and orthopedic surgery to fill bone defects and coat metallic implant surfaces in order to improve implant integration with the host bone. Furthermore, commercial hydroxyapatite (HAP) and $\beta$-tricalcium phosphate $(\beta$-TCP) have been examined in terms of their suitability as a bone substitute in the clinical setting [3]. However, their clinical applications have been limited because of their brittleness, difficulty of shaping, and the extremely slow degradation rate exhibited by HAp [5]. Moreover, the drug loading on the $\beta$-TCP surface takes place by physical adsorption. It is well established that the adsorption capacity is limited, because it mainly depends on the surface area of the material [4].

The use of a synthetic polymer in bone tissue engineering is an alternative strategy widely used nowadays $[6,7]$. The polycaprolactone (PCL), a US food and drug administration (FDA) approved material for craniofacial surgical procedures, is a biocompatible and biodegradable aliphatic polyester, having a low melting point. PCL presents a slow degradation rate (over two years in vivo) and higher elastic modulus when compared to other biodegradable polyesters approved by FDA [8]. In addition, PCL degradation products are easily resorbed through metabolic pathways and do not produce local acidic environments. Thus, it is a prime candidate to be used in bone scaffolding applications [6,9]. The addition of biodegradable polymers such as PCL to calcium phosphate ceramics would allow better manipulation and control over both the macro- and microstructure in shaping composites to fit bone defects.

Recent clinical studies showed that beta blockers and anti hypertension drugs would reduce the risk of bone fractures in the elderly population. This suggests a possible link between the vascular and skeletal systems [10-12].

Angiotensin II (Ang II), a biologically active octapeptide, is a primary effectors of the Renin Angiotensin System (RAS). Ang II mediates hemodynamic, growth, inflammation and metabolic responses in numerous tissues [13]. Osteoblasts and osteoclasts express angiotensin II receptors (AT1 and AT2) in cell cultures [14]. It has been reported that Ang II induces bone resorption, suppresses alkaline phosphatase activity in vitro, and stimulates the proliferation of osteoblasts [13].

Angiotensin-(1-7) was first discovered more than 30 years ago and since then it has been explored in the context of cardiovascular function $[15,16]$. It is well known that it often counteracts the effects caused by angiotensin II [1719]. Similar to Angiotensin-Converting Enzymes (ACE) inhibitors, the majority of the effects of angiotensin II type 1 receptor blockers are reminiscent of angiotensin-(1-7) functions, and there are evidences that angiotensin-(1-7) is also involved in angiotensin II type 1 receptor blocker effects. Of note, angiotensin-(1-7) can interact directly with angiotensin II type 1 receptor [20, 21], leading to the decrease of their functional regulation [22, 23].

In this study, we obtained highly porous threedimensional biodegradable composite scaffolds from betatricalcium phosphate-hydroxyapatite bioceramic (BCP), PCL and Angiotensin-(1-7). We used the solvent casting and particulate leaching methods (SC/PL). The processed scaffolds were characterized by X-ray microtomography ( $\mu$ $\mathrm{CT}$ ). Biocompatibility tests in vitro were also performed.

\section{MATERIALS AND METHODS}

\section{Scaffold processing}

PCL scaffolds were obtained by the solvent casting and particulate leaching techniques (SC/PL). These syntheses were performed as described by Mikos et al. [24] with some modifications. Chloroform (Labscan) and $\mathrm{NaCl}$ (SigmaAldrich) were used as solvent and porogen, respectively. First, PCL was completely dissolved under stirring in chloroform $(0.2 \mathrm{~g} / \mathrm{mL})$ at room temperature. The BCP powder (Einco Biomaterial Ltda, BH, MG, Brazil) was then added to the PCL solution. Its mean particle size was 80-100 mesh. The PCL:BCP weight ratio was fitted to 1:0, 1:1, and $3: 1$. The $\mathrm{NaCl}$ particles were separated into diameter classes from 212 to $355 \mu \mathrm{m}$, according to procedure proposed by the American Society for Testing Materials (ASTM) (Fisher, USA). About $8 \mathrm{~g}$ of the sieved $\mathrm{NaCl}$ particles were added to the PCL solution under sonication (60 s) until highly viscous slurry was formed. Next, $1 \mathrm{~mL}$ of an angiotensin (1-7) solution (Ang- $(1-7) /(\mathrm{HA}+\mathrm{PCL})=0.28 \mathrm{mg} / \mathrm{mL})$ was

Table I - Weight ratios of the components of PCL: $\beta T C P / H A$ scaffolds.

[Tabela I - Proporção em peso dos componente do arcabouço contendo PCL: $\beta T C P / H A ́$ scaffolds.]

\begin{tabular}{ccc}
\hline $\mathrm{G}$ & PCL: $\beta \mathrm{TCP} / \mathrm{HA}(\mathrm{w} / \mathrm{w})$ & Angiotensin-(1-7) \\
\hline $\mathrm{A}$ & $1 / 1$ & No \\
$\mathrm{A} 1$ & $1 / 1$ & Yes \\
$\mathrm{B}$ & $3 / 1$ & No \\
$\mathrm{B} 1$ & $3 / 1$ & Yes \\
$\mathrm{C}$ & $1 / 0$ & No \\
$\mathrm{C} 1$ & $1 / 0$ & Yes \\
\hline
\end{tabular}


added to the slurry. The obtained solution was then poured into Petri dishes and dried at room temperature for 2 days. After the solvent evaporation was completed, the scaffolds were washed with distilled water for two days in order to dissolve away the porogen. It is worth to mentioning that the distilled water was replaced at each six hours. Lastly, the scaffolds were dried under vacuum for $48 \mathrm{~h}$. Table I presents the composition of the tested experimental groups.

\section{Scaffold characterization}

The $\mu$-CT tests were performed using the Skyscan 1172 high-resolution desktop X-ray microtomography system. A CCD camera with $2000 \times 1048$ pixels was used to record the transmission of the $\mathrm{X}$-ray beam through the samples. Three-frame averaging and a rotation step of $0.30^{\circ}$ were used, covering a view of $180^{\circ}$. Smoothing and beam-hardening correction steps were applied to suppress noise and beam hardening artifacts The morphological parameters presented in this work were measured after considering one hundred slices along the analyzed volume in the studied samples. The mean values were obtained by considering a $95 \%$ confidence interval. It is worth to mention that because the polymer phase is almost transparent to the X-rays, it was not taken into consideration in the $\mu$-CT experiments. Thus, only the ceramic phase was considered.

\section{Biocompatibility tests in vitro}

Osteoblasts were isolated from the calvaria of three days old neonatal Wistar rats. The calvaria were dissected and freed from soft tissue, cut into small pieces and rinsed in sterile phosphate-buffered saline without calcium and magnesium. The calvaria pieces were incubated with $1 \%$ trypsin-EDTA for $5 \mathrm{~min}$, followed by four sequential incubations with $2 \%$ collagenase type II at $37{ }^{\circ} \mathrm{C}$ for $45 \mathrm{~min}$ each. The supernatant of the first collagenase incubation, which contain a high proportion of periosteal fibroblasts, were discarded. The other digestions produced a suspension of cells with high proportion of osteoblasts. After centrifugation at $1000 \mathrm{~g}$ for $5 \mathrm{~min}$, each pellet were resuspended in $5 \mathrm{~mL}$ of DMEM (Sigma, St Louis, USA) medium supplemented with $10 \%$ fetal bovine serum (FBS) (GibcoBRL, NY, USA) and 1\% antibiotic-antimycotic solution (GibcoBRL, NY, USA). The cells were seeded into $25 \mathrm{~mL}$ tissue culture flasks, and led to grow in a controlled $5 \%$ $\mathrm{CO}_{2} 95 \%$ humidified incubator at $37^{\circ} \mathrm{C}$. After confluence the cells were used for experiments on passage 2 .

\section{MTT and Alkaline Phosphatase Activity assays}

The Vybrant ${ }^{\circledR}$ MTT Cell Proliferation Assay Kit (Molecular Probes, Eugene, OR) was used in order to measure both cell viability and proliferation. The key component of this method is the 3-(4,5-dimethylthiazol-2-yl)-2,5diphenyl tetrazolium bromide (MTT). The MTT agent can react with the tetrazolium ring (produced by mitochondrial dehydrogenases of living cells) to produce a blue formazan product which can be measured spectrophotometrically. The amount of formazan produced is proportional to the number of viable cells present in the media. In this process

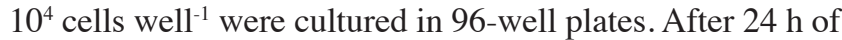
incubation, the culture medium was aspired from the cells and replaced by $100 \mu \mathrm{L}$ of fresh medium containing the composite, the positive control, or the empty vector (blank). The positive control used in this test was lauryl sulphate. After three and seven days, the composites were removed and the cells were rinsed three times with phosphatebuffered saline (PBS) in order to eliminate non-viable cells. Next, $100 \mu \mathrm{L}$ well $^{-1}$ of fresh culture medium was replaced by $10 \mu \mathrm{L}$ of $12 \mathrm{mM}$ MTT stock solution (PBS : MTT $=1 \mathrm{~mL}$ : $5 \mathrm{mg}$ ). The cells were incubated at $37^{\circ} \mathrm{C}$ for $4 \mathrm{~h}$ to allow the formazan crystal formation.

After incubation, the supernatant was removed and 100 $\mu \mathrm{L}$ of the SDS-HCl solution $(0.01 \mathrm{M} \mathrm{HCl}: \mathrm{SDS}=10 \mathrm{~mL}: 1$ $\mathrm{mg}$ ) was added under shaking to each well in order to dissolve the formazan crystals. The absorbance was measured in a Thermo Scientific Multiskan ${ }^{\circledR}$ Spectrum, using a test wavelength of $570 \mathrm{~nm}$. The results from eight individual experiments were averaged. The viability reduction (Viab.) of a given culture cell when compared to the empty vector was estimated by the equation:

$$
\mathrm{Viab}=100 \mathrm{x} \frac{\mathrm{OD}_{570 \mathrm{c}}}{\mathrm{OD}_{570 \mathrm{~b}}}
$$

where $\mathrm{OD}_{570 \mathrm{c}}$ and $\mathrm{OD}_{570 \mathrm{~b}}$ are the measured optical densities for the composites and the blanks, respectively. The lower is the Viab. value, the higher is the cytotoxicity of the culture cell [24].

The alkaline phosphatase production was evaluated by BCIP-NBT assay. This assay is based on a chromagenic reaction initiated by the cleavage of the phosphate group of BCIP by alkaline phosphatase present in the cells. This reaction produces a proton which reduces NBT to an insoluble purple precipitate. Briefly, the supernatant of each well was removed and the cell layer was rinsed twice with PBS. Then, $200 \mu \mathrm{L}$ of BCIP-NBT solution, prepared as manufacturer protocol, was added to each well. After $2 \mathrm{~h}$ of incubation, the cells were observed by optical microscopy and the insoluble purple precipitates were solubilized with $210 \mu \mathrm{L}$ of SDS $10 \% \mathrm{HCl}$ and incubated for $18 \mathrm{~h}$. The optical density measurement was done at $595 \mathrm{~nm}$. Both the MTT activity and alkaline phosphatase activity were evaluated using a one-way ANOVA. Ranking of the means was performed using the Bonferroni multiple-comparison test. P values lower than 0.05 were considered statistically significant.

\section{RESULTS}

\section{Structural morphology}

Figs. 1 and 2 show the three-dimensional reconstructions 


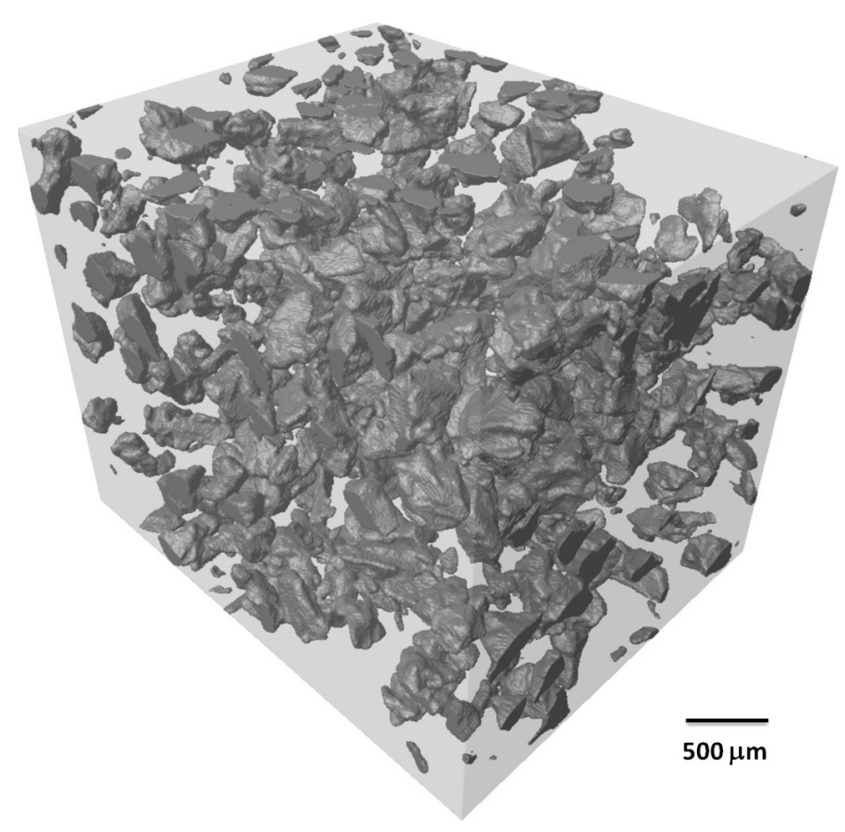

Figure 1: Three dimensional distribution of the ceramic phase in the polymeric matrix (PCL:BC 1:1). Figure generated from the $\mu$-CT data.

[Figura 1: Distribuição tridimensional da fase cerâmica na matriz. polimérica (PCL:BC - 1:1). Figura gerada utilizando dados de microtomografia.]

of samples obtained using PCL:BCP weight ratios of 3:1 and $1: 1$, respectively. From these images one observes that the organic solvent used to dissolve PCL could not effectively disperse the BCP particles. Thus, the BCP particles have agglomerated into larger secondary aggregates. In Table II it is shown the main morphological parameters measured for the analyzed samples. We observed that the increase of the PCL:BCP weight ratio leads to a structure with a lower MPS (mean pore size).

The object perimeter / area ratio (OPAR) is a basic parameter in characterizing the complexity of a structure. According to Frisullo et al. [25], this parameter indicates the pore size distribution within the solid; the higher the value, more finely distributed are the pores within the sample. We noticed that the increase of the PCL:BC weight ratio leads to a structure with a higher value of OPAR. This observation matches with the lower MPS measured for the scaffold obtained using a PCL:BCP weight ratio of $3: 1 . \mathrm{V}_{\mathrm{v}}$ is the volume fraction of the ceramic phase. Increasing the

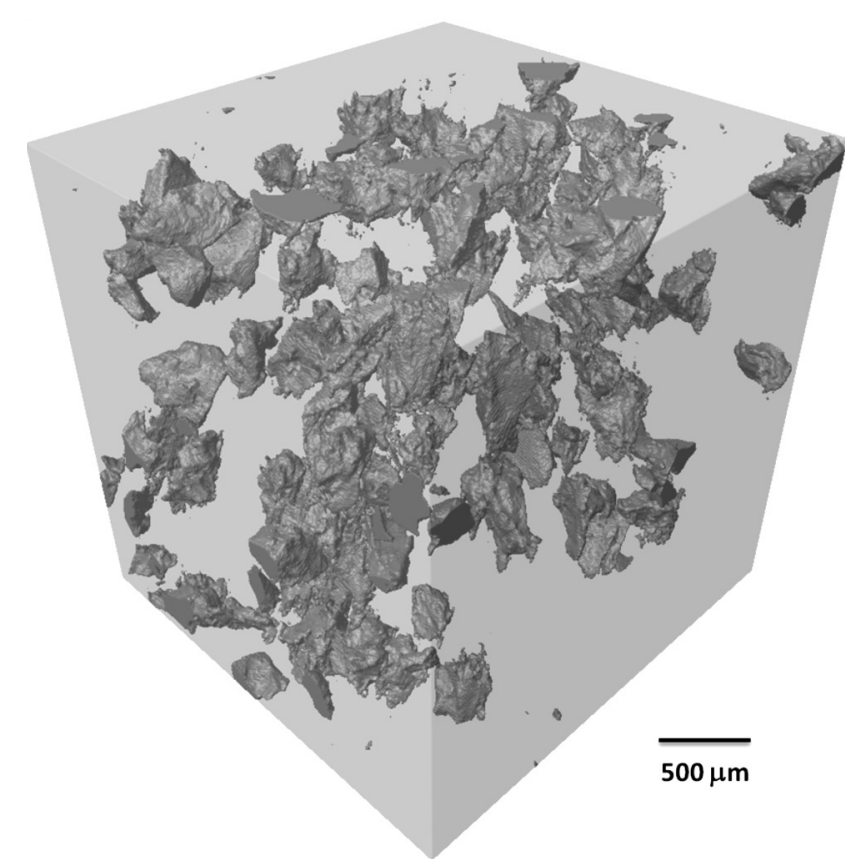

Figure 2: Image three dimensional generated from the $\mu$-CT data showing the distribution of the ceramic phase in the polymeric matrix (PCL:BC - 3:1).

[Figura 2: Figura tridimensional gerada utilizando dados de microtomografia mostrando a distribuição da fase cerâmica na matriz polimérica $(P C L: B C-3: 1)$.]

aforementioned ratio leads to the decrease of the volume fraction of the ceramic phase.

The fragmentation index $(\mathrm{FI})$ is an inverse index of connectivity and it is a measure of the relative convexity or concavity of the pores [26]. It was originally applied by Hahn et al. [27] to 2D images of trabecular bone. A low FI value signifies better-connected solid lattices and has a negative index. On the other hand, a high FI indicates a more disconnected structure and has a positive index [27]. We noticed that both analyzed samples present disconnected structures, with close values of FI. However, it is worth to stress that the polymer phase was not taken into consideration in the $\mu$-CT tests.

The fractal dimension (FD) is an indicator of the complexity of a structure, which quantifies how that structure fills space. A fractal object tends to fill up space and its dimension value is not an integer. Based on this concept, some researchers have proposed that different aspects of the microstructure of materials can be described

Table II - Main morphological parameters measured for the analyzed samples.

[Tabela II - Principais parâmetros morfológicos analisados nas amostras selecionadas.]

\begin{tabular}{llllll}
\hline Sample & MPS $(\mu \mathrm{m})$ & $\mathrm{V}_{\mathrm{V}}(\%)$ & FI $\left(\mu \mathrm{m}^{-1}\right)$ & FD & OPAR $\left(\mu \mathrm{m}^{-1}\right)$ \\
\hline PCL-BC 1-1 & $572 \pm 23$ & $11.7 \pm 0.5$ & $0.010 \pm 0.001$ & $1.063 \pm 0.003$ & $0.035 \pm 0.001$ \\
PCL-BC 3-1 & $486 \pm 37$ & $4.6 \pm 0.4$ & $0.006 \pm 0.001$ & $1.092 \pm 0.005$ & $0.046 \pm 0.001$ \\
\hline
\end{tabular}

* MPS: mean pore size; $V_{V}$ : volume fraction of the ceramic phase ; FI: fragmentation index; FD: fractal dimension; OPAR: object perimeter/area ratio.

* MPS: Tamanho médio de poros; $V_{V}$ Fração volumétrica da fase cerâmica ; FI: Índice de fragmentação; FD: Dimensão fractal; OPAR: Perímetro do objeto/proporção da área. 
as a fractal. With regard to porosity, FD informs us about the spatial distribution of pores within the sample[28].

There are many specific definitions of fractal dimension and the computational ways to obtain them vary considerably $[29,30]$. In the software used (CTAnalyzer), FD is calculated using the Kolmogorov or "box counting" method. Since the morphological parameters presented in this work were measured after considering a series of slices along the analyzed volume for all samples, FD must lie between 1 and 2. As shown in Table II, the higher the PCL:BC weight ratio, higher is FD.

\section{MTT and Alkaline Phosphatase Activity assays}

Fig. 3 shows the amount of viable cells of the composites determined by the MTT assay after incubation times of three and seven days. The amount of viable cells at three and seven days of incubation significantly depends on the content of the Ang-(1-7) $(\mathrm{p}<0.05)$. We observed that the $\mathrm{A} 1$ and $\mathrm{B} 1$ groups exhibit lower cell viability than $\mathrm{C} 1$. It is worth to point out that the presence of the Ang-(1-7) has decreased the measured amount of viable cells in all analyzed culture media.

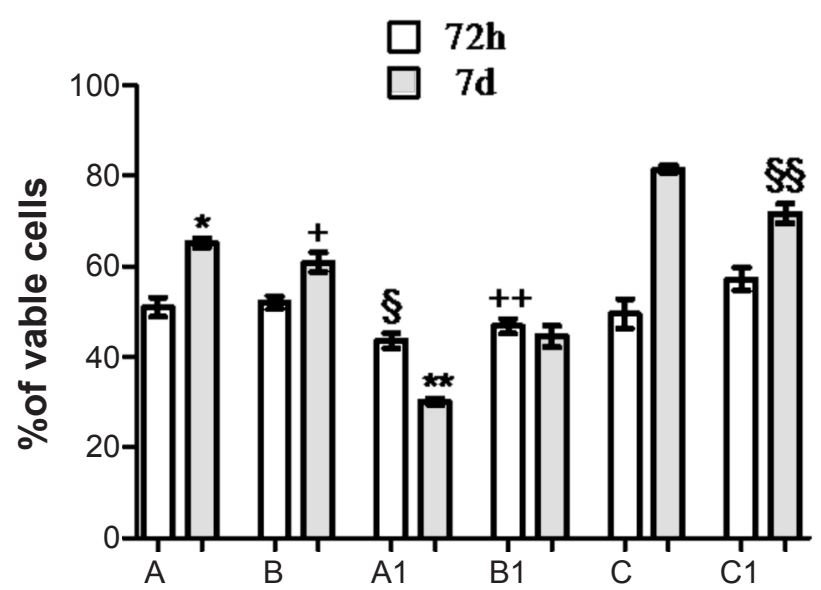

Figure 3: Percentage of viable cells relative to the culture plate control following $72 \mathrm{~h}$ and 7 days' growth on composites (* represents the significant difference of the composite A compared with $\mathrm{A} 1, \mathrm{~B} 1$, and $\mathrm{C} ;{ }^{+}$represents the significant difference of the composite B compared with $\mathrm{A}, \mathrm{B}, \mathrm{C}$, and $\mathrm{C} 1 ;{ }^{\S}$ represents the significant difference between $\mathrm{A} 1$ and $\mathrm{C} 1$ during three days; ** represents the significant difference of the composite A1 compared with all others during seven days; ${ }^{++}$represents the difference between $\mathrm{B} 1$ and $\mathrm{C} 1$, and ${ }^{\S}$ represents the difference between $\mathrm{C}$ and $\mathrm{C} 1$ ). Results represent mean \pm SD of eight samples from two separate experiments $(\mathrm{p}<0.05)$.

[Figura 3: Porcentagem de células viáveis nos grupos testados relacionada ao grupo controle no período de 72 h e 7 dias (* representa diferença significativa do compósito A comparado com $A 1, B 1$, e $C ;{ }^{+}$representa diferença significativa do compósito $B$ comparado com $A, B, C, e C 1 ;{ }^{\S}$ representa diferença significativa do compósito $A 1$ e $C 1$ durante três dias; ** representa diferença significativa do compósito Al comparado a todos os demais grupos; ${ }^{++}$representa diferença significativa entre os compósitos $B 1$ e $C 1, e^{\S \S}$ representa diferença significativa entre os compósitos $C$ e Cl $(p<0,05)$.]

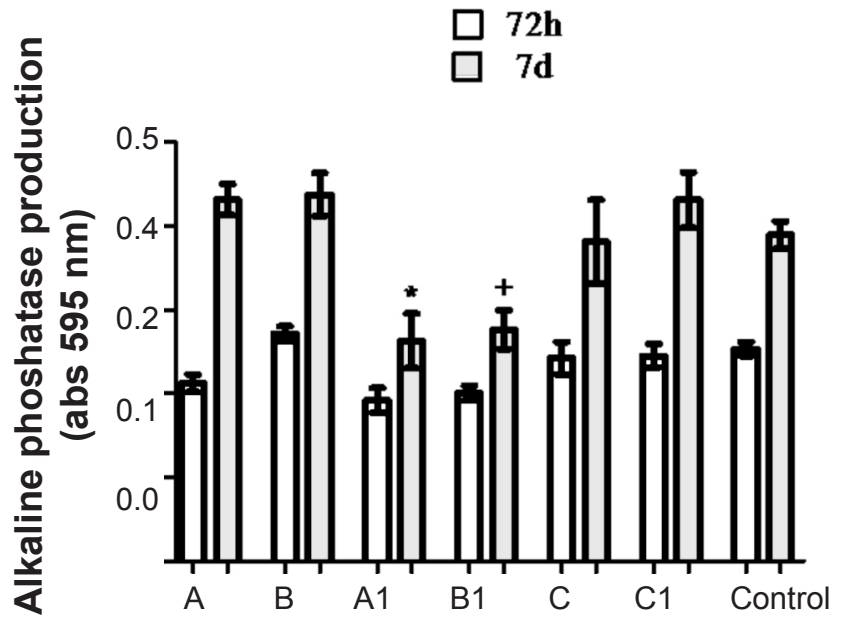

Figure 4: Alkaline phosphatase production of osteoblasts after three and seven days of incubation: cells showed no significant difference in presence of the composites ( $\mathrm{A}, \mathrm{B}, \mathrm{C}$ and $\mathrm{C} 1)$ when compared to control cells $(*$ represents the significant difference of the composite A1 compared with A, B, C1, and Control during seven days'; + represents the significant difference of the composite $\mathrm{B} 1$ compared with $A, B$, and $C 1)$. Results represent mean \pm SD of eight samples from two separate experiments $(\mathrm{p}<0.05)$.

[Figura 4: Produção de fosfatase alcalina após três e sete dias de incubação: não houve diferença significativa na presença dos compósitos ( $A, B, C$ e $C 1$ ) quando comparado com o grupo controle (* representa diferença significativa do compósito Al comparado com $A, B, C 1$ e Controle durante sete dias; ${ }^{+}$representa diferença significativa do compósito B1 comparado com A, B e C1), $(p<0,05)$.]

The alkaline phosphatase production of the osteoblasts in presence of the Ang-(1-7) composites was similar to that observed for the control cells (Fig. 4). The osteoblasts, when in contact for three days with the PCL composites, also presented an alkaline phosphatase production similar to that observed for the control cells. For an incubation time of seven days, the A1 and B1 groups exhibit significantly lower alkaline phosphatase production than $\mathrm{A}, \mathrm{B}, \mathrm{C} 1$ and the control sample.

\section{DISCUSSION}

The complex architecture and variability of properties of bone tissue (e.g. porosity, pore size, mechanical properties and cytokines gradient features), as well as differences in age, nutritional state, activity and disease status of individuals, establish a major challenge in fabricating scaffolds that meet the needs of specific repair sites in specific patients [31]. A key issue to compensate the complexity of bone tissue is to achieve a fast replacement of bone substitute with new mature bone. In this work an organic-inorganic composite material suitable for bone tissue engineering and based on BCP, PCL and angiotensin-(1-7) was studied. Therefore, the strategy of obtaining highly porous three-dimensional scaffolds from biphasic ceramics and degradable polymers is a promising method to develop composite systems for application in hard tissue regeneration [2]. PCL is a semi- 
crystalline, bioresorbable polymer which belongs to the aliphatic polyester group. It is well known for its slow degradation rate [6]. Because of this property it has been widely used in several clinical applications, including as temporary joint spacer and matrix in the fabrication of composite bone substitutes [9].

According to LeGeros [32] $\beta$-TCP is a bioactive and biocompatible ceramic that has a stoichiometry similar to amorphous biological precursors to bone. It is protein free and elicits minimal immunological and foreign body reactions. In addition, calcium phosphates also posses osteoconductive abilities and can bind directly to bone. The presence of $\mathrm{BCP}$ in the composite material beneficially offsets the acidic release from the PCL through the alkaline calcium phosphate and mitigates erosion events associated with the release of acidic degradation products. In vivo and in vitro measurements of $\mathrm{pH}$ in bone chambers have shown that the $\mathrm{pH}$ drop is about 0.2 near the eroding polymer [2]. The BCP provides mechanical anchorage for osteoblastic cells and a more favorable surface for cell attachment, which determines the ability of the material to support bone ingrowth or to act as a biological template [3]. A bone tissue engineering scaffold should be able in some cases to provide mechanical support at the implantation site for up to a year postoperatively [6]. During this time, neo-tissues would ingress the site, form neo-bone and remodel. In this study, PCL scaffolds intended for use in bone tissue engineering were obtained by solvent casting and particulate leaching techniques. This combined method has been reported to be a promising method to obtain porous structures suitable for bone tissue engineering [9]. As an apatite/ polymer composite, the PCL/BCP we obtained mimics the components of natural bones, were $\mathrm{BCP}$ is distributed in the PCL matrix (see Figs. 1 and 2).

The porosity can be defined as the amount of void space in a solid and it is a geometrical property independent of the material. According to Karageorgiou and Kaplan (2005) [33], the minimum requirement for pore size is considered to be $100 \mu \mathrm{m}$ due to cell size, migration requirements and transport. However, pore sizes greater than $300 \mu \mathrm{m}$ are recommended, due to the improved formation of new bone and capillaries [34]. According to Chuenjitkuntaworn et al. [6], excellent ingrowth of bone cells has been observed in scaffolds with pore sizes greater than $400 \mu \mathrm{m}$. As presented in Table II, the $\mu$-CT tests revealed mean pores sizes of about $486 \pm 37$ and $571 \pm 23 \mu \mathrm{m}$. Because of vascularization, pore size has been shown to affect the progression of osteogenesis. Small pores favored hypoxic conditions and induced osteochondral formation before osteogenesis, while large pores, that are well vascularized, lead to direct osteogenesis (without preceding cartilage formation). Our results on the scaffold porosity do not agree with those obtained by Chuenjitkuntaworn et al. [6]. They showed that the addition of BC particles in PCL scaffolds did not affect the scaffolds porosities. Pores are necessary for bone tissue formation because they allow migration, proliferation and ALP activity of osteoblasts and mesenchymal cells [7].
Nevertheless, pore diameter is not the only one important parameter in an experimental setting; other parameters, including implant chemistry, implant topography, resorption and pore interconnectivity must be considered.

It was proposed by some researchers that in resorbable materials, pore density and interconnection density are more important than pore size $[31,33]$. Thus, an incomplete pore interconnection could constrain the overall biological system and limit the blood vessel invasion, which is essential for tissue ingrowth into the porous scaffolds [35]. According to Bohner and Baumgart (2004) [36], bone ingrowth should not be affected by the pore diameter as long as the structure is fully interconnected and the pore interconnections have a diameter larger than $50 \mu \mathrm{m}$. Although the increase of both porosity and pore size induce bone ingrowth, it compromises the structural integrity of the scaffold [30, 36, 37].

Based on the results presented in this study, we believe that the lower is the fragmentation index, the higher is the osteogenic differentiation in vitro (ALP activity). ALP activity is an important parameter to measure the osteogenic differentiation [38]. However, we observed that both samples analyzed by $\mu$-CT presented close values of FI and no considerable differences in the ALP activity (see Fig. 4). This may be related to the hydrophobic character of BCP and PCL, which results in a non-homogeneous distribution of the BCP particles within the PCL matrix. Organic solvents normally used to dissolve PCL could not effectively disperse the BCP particles [38]. Therefore, the $\mathrm{BCP}$ particles have agglomerated into larger secondary aggregates (see Figs. 1 and 2). These BCP agglomerates act as a source of failure, decreasing pore interconnectivity. On the basis of these results we should used a surfactant to mediated the interaction between the hydrophilic BCP and the hydrophobic PCL, to create a homogeneous dispersion of BCP particles within the polymer matrix [39].

Schlienger et al. [40] observed that the long term use of angiotensin-converting enzyme (ACE) inhibitors is associated with a decrease in the risk of bone fracture. However, the actual mechanism by which ACE inhibitors influence bone mass is not well understood. Some researchers believe that this therapeutic effect takes place due to the deacrease of angiotensin II levels [41]. Angiotensin (Ang II) is a biologically active octapeptide, and a primary effector RAS. It mediates hemodynamic, growth, the inflammatory process, and the metabolic response in numerous tissues, including the heart, arteries, liver, bone and kidney. This compound acts through two distinct subtypes of cell-surface receptors, the AT1 and AT2 receptors, while osteoblasts express both receptors $[14,42]$.

The AT1 receptor is required for Ang II induced IL-6 secretion in osteoblasts. IL-6 plays an indispensable role in bone metabolism, which is regulated by a balance between bone formation and resorption by the osteoclasts. IL-6 is recognized to act as a bone resorbing factor, inducing osteoclast formation and stimulating bone resorption [13]. It is well established that Angiotensin-(1-7) often counteracts the effects caused by angiotensin II. This makes this 
compound an important study subject in both experimental and pharmacological areas [43].

There is now a model concept about the RAS which has been established in human and rat. This concept says that the RAS has two axes, the angiotensin-converting enzyme (ACE)-AngII type (AT) 1 receptor axis and the angiotensin-converting enzyme-related carboxypeptidase (ACE 2)-Ang-(1-7)-Mas axis. The former axis performs the vasoconstrictive, proliferative and pro-inflammatory functions through the major player AngII, the latter axis always counteracts on the effects of former through the major effector, Ang-(1-7). Ang-(1-7) inhibit a lot of process stimulated by Ang II, such as vasoconstriction, proliferation of osteoblast-rich populations of cells, prothrombogenic actions and fibrogenic responses [42, 44]. All of those process stimulated by Ang II are mediated by AT 1 receptor, and Ang-(1-7) takes inhibitory effects via a specific receptor, the G-protein-coupled receptor Mas [38]. The Mas receptor is reported to antagonize AT1 receptor through the formation of a hetero-oligomeric complex in cultured mammalian cells $[45,46]$. The present study clearly demonstrates a negative correlation between cell proliferation and Ang-(1-7) content (see Fig. 3). However, this negative correlation doesn't characterize the citotoxic level [47] and could be used in vivo tests.

\section{CONCLUSION}

In conclusion, we obtained by the solvent casting and particulate leaching methods highly porous threedimensional biodegradable scaffolds from beta-tricalcium phosphate-hydroxyapatite bioceramic (BCP), PCL, and Angiotensin-(1-7). The obtained scaffolds presented suitable forms for filling bone defects. Furthermore, the in vitro tests revealed that the processed scaffolds have potential for use in drug delivery systems.

\section{ACKNOWLEDGMENTS}

The authors thanks for financially support by INCTCNPq NanoBiofar and FAPEMIG, Brazilian agencies.

\section{REFERENCES}

[1] J. He, D. G. Genetos, J. K. Leach, Osteogenesis and trophic factor secretion are influenced by the composition of hydroxyapatite/poly(lactide-co-glycolide) composite scaffolds, Tissue Eng. Part A 16 (2010) 127-37.

[2] M. G. Raucci, V. D’Antò, V. Guarino, E. Sardella, S. Zeppetelli, P. Favia, Biomineralized porous composite scaffolds prepared by chemical synthesis for bone tissue regeneration, Acta Biomater. 6 (2010) 4090-9.

[3] H.Cao, N. Kuboyama, A biodegradable porous composite scaffold of PGA/beta-TCP for bone tissue engineering, Bone 46 (2010) 386-95.

[4] W. Xue, A. Bandyopadhyay, S. Bose, Polycaprolactone coated porous tricalcium phosphate scaffolds for controlled release of protein for tissue engineering, J. Biomed. Mater.
Res. B Appl. Biomaterials 91 (2009) 831-8.

[5] S. S. Kim, M. Sun Park, O. Jeon, C. Yong Choi, B. S. Kim, Poly(lactide-co-glycolide)/hydroxyapatite composite scaffolds for bone tissue engineering, Biomaterials 27 (2006) 1399-409.

[6] B. Chuenjitkuntaworn, W. Inrung, D. Damrongsri, K. Mekaapiruk, P. Supaphol, P. Pavasant, Polycaprolactonel hydroxyapatite composite scaffolds: preparation, characterization, and in vitro and in vivo biological responses of human primary bone cells, J. Biomed. Mater. Res. A 94 (2010) 241-51.

[7] Z. Ge, Z. Jin, T. Cao, Manufacture of degradable polymeric scaffolds for bone regeneration, Biomed. Mater. 3 (2008) 022001.

[8] J. R. Porter, T. T. Ruckh, K. C. Popat, Bone tissue engineering: a review in bone biomimetics and drug delivery strategies, Biotechnol. Prog. 25 (2009) 1539-60.

[9] T. Cao, K. H. Ho, S. H. Teoh, Scaffold design and in vitro study of osteochondral coculture in a three-dimensional porous polycaprolactone scaffold fabricated by fused deposition modeling, Tissue Eng. 9 (2003) S103-12.

[10] R. G. Schlienger, M. E. Kraenzlin, S. S. Jick, C. R. Meier, Use of beta-blockers and risk of fractures, JAMA 292 (2004) 1326-32.

[11] H. Lynn, T. Kwok, S. Y. S. Wong, J. Woo, P. C. Leung, Angiotensin converting enzyme inhibitor use is associated with higher bone mineral density in eldery Chinese, Bone 38 (2006) 584-588.

[12] I. R. Reid, G. D. Gamble, A. B. Grey, D. M. Black, K. E. Ensrud, W. S. Browner, D. C. Bauer, Beta-Blocker use, $B M D$, and fractures in the study of osteoporotic fractures, $\mathrm{J}$. Bone Miner. Res. 20 (2005) 613-8.

[13] L. Guo, M. Wang, Z. Y. Zhang, L. Hao, B. Y. Lou, X. Y. Li, W. T. Loo, L. Jin, M. N. Cheunq, Angiotensin II induces interleukin-6 synthesis in osteoblasts through ERK1/2 pathway via AT1 receptor, Arch. Oral Biol. 56, 3 (2011) 205-11.

[14] Izu Y, F. Mizoguchi, A. Kawamata, T. Hayata, T. Nakamoto, K. Nakashima, T. Inagamati, Y. Ezura, M. Noda, Angiotensin II type 2 receptor blockade increases bone mass, J. Biol. Chem. 284, 8 (2009) 4857-64.

[15] R. A. Santos, A. J. Ferreira, Angiotensin-(1-7) and the renin-angiotensin system, Curr. Opin. Nephrol Hypertens 16 (2007) 122-8.

[16] A. J. Ferreira, B. A. Jacoby, C. A. Araújo, F. A. Macedo, G. A. Silva, A. P. Almeida, M. V. Caliari, R. A. Santos, The nonpeptide angiotensin-(1-7) receptor Mas agonist AVE-0991 attenuates heart failure induced by myocardial infarction, Am. J. Physiol. Heart Circ. Physiol. 292, 2 (2007) H1113-9.

[17] M. T. Schiavone, R. A. Santos, K. B. Brosnihan, M. C. Khosla, C. M. Ferrario, Release of vasopressin from the rat hypothalamo-neurohypophysial system by angiotensin-(1-7) heptapeptide, Proc. Natl. Acad. s Sci. 85 (1988) 4095-8.

[18] R. A. Santos, M. J. Campagnole-Santos, S. P. Andrade, Angiotensin-(1-7): an update, Regul. Pept. 91, 1-3 (2000) 45-62.

[19] B. P. Rowe, D. L. Saylor, R. C. Speth, D. R. Absher, 
Angiotensin-(1-7) binding at angiotensin II receptors in the rat brain, Regul. Pept. 56 (1995) 139-46.

[20] N. H. Garcia, J. L. Garvin, Angiotensin 1-7 has a biphasic effect on fluid absorption in the proximal straight tubule, J. Am. Soc. Nephrol. 5 (1994) 1133-8.

[21] V. Vallon, N. Heyne, K. Richter, M. C. Khosla, K. Fechter, [7-D-ALA]-angiotensin 1-7 blocks renal actions of angiotensin 1-7 in the anesthetized rat, J. Cardiovasc. Pharmacol. 32 (1998) 164-7.

[22] Z. Zhu, J. Zhong, S. Zhu, D. Liu, M. Van Der Giet, M. Tepel, Angiotensin-(1-7) inhibits angiotensin II-induced signal transduction, J. Cardiovasc. Pharmacol. 40 (2002) 693-700.

[23] M. K. Raizada, A. J. Ferreira, ACE2: a new target for cardiovascular disease therapeutics, J. Cardiovasc. Pharmacol. 50 (2007) 112-9.

[24] A. G. Mikos, D. M. Lyman, L. E. Freed, R Langer, Wetting of poly (L-lactic acid) and poly (DL-lactic-co glycolic acid) foams for tissue culture, Biomaterials 15 (1994) 55-8.

[25] P. Frisullo, A. Conte, N. A. Nobile, A novel approach to study biscuits and breadsticks using X-ray computed tomography, J. Food Sci. 75 (2010) E353-8.

[26] K. S. Lim, M. Barigou, X-ray micro-computed tomography of cellular food products, Food Res. Int. 37 (2004) 1001-12.

[27] M. Amling, M. Hahn, V. J. Wening, H. J. Grote, G. Delling, The microarchitecture of the axis as the predisposing factor for fracture of the base of the odontoid process, A histomorphometric analysis of twenty-two autopsy specimens, J. Bone Joint Surg. Am. 76 (1994) 1840-6.

[28] M. Hahn, M. Vogel, Pompesius-Kempa M and Delling $G$, Trabecular bone pattern factor-a new parameter for simple quantification of bone microarchitecture, Bone 13 (1992) 327-30.

[29] D. Chappard, E. Legrand, B. Haettich, G. Chalès, B. Auvinet, J. P. Eschard, M. F. Baslé, M. Audran, Fractal dimension of trabecular bone: comparison of three histomorphometric computed techniques for measuring the architectural two-dimensional complexity, J. Pathol. 195, 4 (2001) 515-21.

[30] S. S. Cross, The application of fractal geometric analysis to microscopic images, Micron 25 (1994) 101-13.

[31] P. Kasten, I. Beyen, P. Niemeyer, R. Luginbühl, M. Bohner, W. Richter, Porosity and pore size of beta-tricalcium phosphate scaffold can influence protein production and osteogenic differentiation of human mesenchymal stem cells: an in vitro and in vivo study, Acta Biomater. 4 (2008) 1904-15.

[32] R.Z.LeGeros, Calcium phosphate-based osteoinductive materials, Chem. Rev. 108 (2008) 4742-53.

[33] V. Karageorgiou, D. Kaplan, Porosity of 3D biomaterial scaffolds and osteogenesis, Biomaterials 26 (2005) 5474-91.

[34] M. C. von Doernberg, B. von Rechenberg, M. Bohner, S. Grünenfelder, G. H. van Lenthe, R. Müller, B. Gasser, R. Mathys, G. Baround, J. Auer, In vivo behavior of calcium phosphate scaffolds with four different pore sizes,
Biomaterials 27, 30 (2006) 5186-98.

[35] S. I. Roohani-Esfahani, S. Nouri-Khorasani, Z. Lu, R. Appleyard, H. Zreiqat, The influence hydroxyapatite nanoparticle shape and size on the properties of biphasic calcium phosphate scaffolds coated with hydroxyapatitePCL composites, Biomaterials 31 (2010) 5498-509.

[36] M. Bohner, F. Baumgart, Theoretical model to determine the effects of geometrical factors on the resorption of calcium phosphate bone substitutes, Biomaterials 25 (2004) 3569-82.

[37] S. S. Kim, M. Sun Park, O. Jeon, C. Yong Choi, B. S. Kim, Poly(lactide-co-glycolide)/hydroxyapatite composite scaffolds for bone tissue engineering, Biomaterials 27 (2006) 1399-409.

[38] Y. Kuboki, H. Takita, D. Kobayashi, E. Tsuruga, M. Inoue, M. Murata, N. Nagai, Y. Dohi, H. Ohgushi, BMPinduced osteogenesis on the surface of hydroxyapatite with geometrically feasible and nonfeasible structures: topology of osteogenesis, J. Biomed. Mater. Res. 39, 2 (1998) 190-9.

[39] H. W. Kim, Biomedical nanocomposites of hydroxyapatite/polycaprolactone obtained by surfactant mediation, J. Biomed. Mater. Res. A 83 (2007) 169-77.

[40] R. G. Schlienger, M. E. Kraenzlin, S. S. Jick, C. R. Meier, Use of beta-blockers and risk of fractures, JAMA 292 (2004) 1326-32.

[41] Y. Asaba, M. Ito, T. Fumoto, K. Watanabe, R. Fukuhara, S. Takeshita, Y. Nimura, J. Ishida, A. Fukamizu, K. Ikeda, Activation of Renin-Angiotensin System induces osteoporosis independently of hypertension, J. Bone Miner. Res. 24, 2 (2009) 241-50.

[42] D. Iusuf, R. H. Henning,W. H. Van Gilst, A. J. Roks, Angiotensin-(1-7): pharmacological properties and pharmacotherapeutic perspectives, Eur. J. Pharmacol. 585 (2008) 303-12.

[43] H. Shimizu, H. Nakagami, M. K. Osako, R. Hanayama, Y. Kunugiza,T. Kizawa,T. Tomita,H. Yoshikawa,T. Ogihara, R. Morishita, Angiotensin II accelerates osteoporosis by activating osteoclasts, FASEB J. 22, 7 (2008) 2465-75.

[44] Y. Hiruma, A. Inoue, S. Hirose, H. Hagiwara, Angiotensin II stimulates the proliferation of osteoblast-rich populations of cells from rat calvariae, Biochem. Biophys. Res. Commun. 230 (1997) 176-8.

[45] W. Nie, H. Yan, S. Li, Y. Zhang, F. Yu, W. Zhu, F. Fan, J. Zhu, Angiotensin-(1-7) enhances angiotensin II induced phosphorylation of ERK1/2 in mouse bone marrow-derived dendritic cells, Mol. Immunol. 46 (2009) 355-61.

[46] E. Kostenis, G. Milligan, A. Christopoulos, C. F. Sanchez-Ferrer, S. Heringer-Walther, P. M. Sexton, F. Gembardt, E. Kellett, L. Martini, P. Vanderheyden, H. P. Schultheiss, T. Walther, G-protein-coupled receptor Mas is a physiological antagonist of the angiotensin II type 1 receptor, Circulation 111, 14 (2005) 1806-13.

[47] ISO, Biological evaluation for medical devices, Part 5: tests for cytotoxicity: in vitro methods, International Standards Organization, ISO/10993-5, London (1994).

(Rec 25/10/2011, Rev. 13/01/2012, Ac. 10/03/2012) 